\title{
Pemanfaatan Kulit Pisang Kepok (Musa paradisiaca) dalam Pembuatan Bolu Kukus
}

\author{
Aprilia Indah Pangestika ${ }^{1}$, Mia Srimiati ${ }^{2}$ \\ 1,2 Program Studi Gizi, Universitas Binawan, Jakarta, Indonesia \\ Email : msrimiati@gmail.com
}

\begin{abstract}
This study aims to determine the substitution effect of banana peel flour based on the proximate tests (water content, ash, carbohydrate, protein, fat and fiber). This experimental study used Completely Randomized Design (CRD) to find out the best quality of banana skin flour with the substitution level of kepok banana peel as a treatment. There were 4 treatments, $F_{1}(45 \%), F_{2}$ $(50 \%), F_{3}(55 \%)$ and $F_{0}$ (without kepok banana peel flour). Based on the results of statistical tests using Analysis of V ariance (ANOV A and Duncan's Multiple Range Test, substitution of kepok banana peel flour has a significant effect $(p<0.05)$ on the organoleptic properties. Steamed sponge cake substituted with 50\% kepok banana peel flour $\left(\mathrm{F}_{2}\right)$ was the formula with the highest acceptability compared to other formulas. Formula $F_{2}(50 \%)$ showed the water content of $31,60 \%$, ash level 2,78\%, fat 5,97\%, protein 10,97\%, fiber 1,91\%, and carbohydrate 48,68\%. Kepok banana peel flour can be used as an alternative to diversification of food and increase the nutritional value of steamed sponge cake.
\end{abstract}

Keyword: Steamed sponge cake, kepok banana peels flour, substitution

\begin{abstract}
Abstrak
Penelitian ini bertujuan untuk mengetahui pengaruh substitusi tepung kulit pisang kepok berdasarkan uji proksimat (kadar air, abu, karbohidrat, protein, lemak dan serat). Penelitian ini merupakan penelitian eksperimental menggunakan Rancangan Acak Lengkap (RAL) untuk mengetahui kualitas tepung kulit pisang terbaik dengan tingkat subsitusi tepung kulit pisang kepok sebagai perlakuan, yaitu $\mathrm{F}_{1}(45 \%), \mathrm{F}_{2}(50 \%), \mathrm{F}_{3}(55 \%)$ dan $\mathrm{F}_{0}$ (tanpa tepung kulit pisang kepok). Berdasarkan hasil uji statistik menggunakan Analysis of Variance (ANOVA) dan Duncan's Multiple Range Test, substitusi tepung kulit pisang kepok berpengaruh signifikan $(\mathrm{P}<0,05)$ terhadap hasil organoleptik produk. Bolu kukus yang disubstitusi tepung kulit pisang kepok sebanyak 50\% $\left(\mathrm{F}_{2}\right)$ merupakan formula dengan daya terima paling tinggi dibandingkan dengan formula lain. Formula $\mathrm{F}_{2}(50 \%)$ memiliki kadar air 31,60\%, abu $2,78 \%$, lemak $5,97 \%$, protein $10,97 \%$, serat $1,91 \%$, karbohidrat $48,68 \%$. Tepung kulit pisang kepok dapat dijadikan alternatif sebagai diversifikasi pangan dan meningkatkan nilai gizi pada bolu kukus.
\end{abstract}

Kata Kunci: Bolu kukus, tepung kulit pisang kepok, substitusi 


\section{PENDAHULUAN}

Pisang merupakan salah satu buah yang banyak dikonsumsi di Indonesia. Berdasarkan data dari Badan Pusat Statistik (2017), total konsumsi pisang per kapita di Indonesia pada tahun 2016 mencapai 5,89 kg/tahun disusul dengan buah rambutan 4,38 kg/tahun dan jeruk 3,59 kg/tahun, dengan jumlah produksi tahunan sebanyak 7,17 juta ton. Salah satu jenis pisang yang paling banyak dikonsumsi adalah pisang kepok (Musa paradisiaca) yang biasanya dimanfaatkan sebagai bahan dasar pembuatan pisang goreng dan keripik pisang.

Pisang kepok (Musa paradisiaca) selain rasanya yang enak, pisang ini juga memiliki kandungan zat gizi yang baik. Setiap $100 \mathrm{~g}$ pisang mengandung energi sebesar $89 \mathrm{kkal}$, karbohidrat 22,84 g, serat 2,6 g, lemak 0,33 g, protein 1,09 g (USDA Nutrient Database, 2018). Konsumsi pisang yang tinggi dapat memicu masalah baru, yaitu tingginya jumlah kulit pisang (yang jika tidak dimanfaatkan) akan berpotesi menjadi limbah. Oleh karena itu, perlu dilakukan penelitian untuk memanfaatkan hasil samping pisang (kulit) tersebut dan meningkatkan nilai tambahnya baik dari segi ekonomis maupun kandungan gizi.

Pengolahan kulit pisang menjadi tepung dapat menjadi alternatif, selain untuk meningkatkan nilai tambahnya juga dapat memperpanjang masa simpan hasil samping pisang (kulit). Tepung kulit pisang dapat dimanfaatkan sebagai pengganti tepung terigu karena sama-sama memiliki pati, memiliki kandungan gizi yang dapat dimanfaatkan dan telah memenuhi syarat SNI tepung terigu. Menurut Djunaedi (2006), kandungan zat gizi pada tepung kulit pisang kepok yaitu air 2,05\% (SNI tepung terigu maksimal. 14,5\%), abu 1,1\%, lemak 4,4\%, protein 9,86\% (SNI tepung terigu minimal 7,0\%), karbohidrat 82,59\%, serat pangan 32,73\%. Di Indonesia tepung terigu memiliki harga yang relatif mahal, hal ini dikarenakan Indonesia masih bergantung pada impor gandum dari negara lain. Impor gandum di Indonesia sepanjang 2017 mencapai 11,4 juta ton. Volumenya meningkat 9\% dibandingkan dengan realisasi 2016 yang sebesar 10,53 juta ton (Badan Pusat Statistik, 2017).

Seperti halnya tepung biji alpukat yang dapat dimanfaatkan menjadi sponge cake (Megarani \& Srimiati, 2018) serta tepung kimpul pada pembuatan bolu (Kumara \& Purwani, 2017) tepung kulit pisang juga dapat dimanfaatkan pada proses pembuatan makanan, sebelumnya tepung kulit pisang telah dimanfaatkan menjadi cookies oleh Djunaedi (2006). Selain itu, tepung kulit pisang kepok juga dapat dimanfaatkan untuk substitusi tepung terigu pada pembuatan bolu kukus, yang merupakan salah satu kue tradisional yang sedang banyak diminati saat ini. Namun demikian, belum ditemukannya formulasi dan metode yang tepat untuk menghasilkan bolu kukus dari substitusi tepung kulit pisang kepok yang optimal dan menghasilkan bolu kukus yang dapat diterima oleh masyarakat. 


\section{METODE}

\section{Desain, Waktu, dan Tempat}

Penelitian ini menggunakan desain penelitian eksperimental dengan model rancangan percobaan Rancangan Acak Lengkap (RAL). Substitusi tepung kulit pisang kepok terhadap tepung terigu dengan formulasi menggunakan metode trial and error yaitu 0\%, 45\%, 50\%, dan 55\%. Tempat Pembuatan bolu kukus tepung kulit pisang dilakukan di kediaman peneliti yang beralamat di Tambun, Bekasi Timur. Adapun formulasi substitusi tepung terigu dengan tepung kulit pisang kepok dilakukan di Laboratorium Kuliner Universitas Binawan serta pengujian organoleptik dan fisik dilakukan di Laboratorium Kuliner Universitas Binawan. Analisis kandungan gizi dilakukan di Laboratorium Kimia Terpadu Institut Pertanian Bogor. Waktu penelitian ini dilakukan pada bulan Januari 2019, dimana proses pembuatan tepung kulit pisang kepok dan bolu kukus, serta pengujian organoleptik, fisik, dan analisis kandungan gizi dilakukan pada bulan yang sama.

\section{Alat dan Bahan}

Alat yang digunakan adalah pisau, timbangan makanan, kompor, mixer, panci kukusan, loyang, sendok, pengaduk, baskom, pipet tetes, timbangan analitik, alat-alat gelas penunjang serta seperangkat alat uji organoleptik. Bahan yang digunakan tepung kulit pisang kepok yang diperoleh dari proses pengovenan ( $\mathrm{T}: 60^{\circ} \mathrm{C}, \mathrm{t}: 12$ jam), tepung terigu protein sedang, telur, margarin, gula pasir, bahan pelembut/emulsifier (SP), baking powder, dan susu.

\section{Pengolahan dan Analisis Data}

Data yang didapatkan dianalisis dengan uji statistik menggunakan Analysis of Variance (ANOVA). Jika ANOVA menunjukkan pengaruh perlakuan nyata (pada jenjang nyata 0,05), maka dilanjutkan dengan Duncan's Multiple Range Test untuk mencari keberadaan perbedaan dari perlakuan yang ada. Analisis kandungan gizi yang dilakukan adalah (uji proksimat) kadar air dengan metode gravimetri, (AOAC, 2012) kadar abu dengan teknis pengabuan kering (AOAC, 2012), karbohidrat dengan metode by difference (Apriyantono et al., 1989), protein dengan metode kjeldhal, lemak dengan ekstraksi soxhlet, dan serat (AOAC, 2012). Analisis perbedaan perlakuan menggunakan uji beda (Independent Simple T-test). 


\section{Tahapan Penelitian}

\section{Proses Pembuatan Tepung Kulit Pisang Kepok (Syahrudin, et al. 2015 yang dimodifikasi)}

Kulit pisang kepok yang akan diolah menjadi tepung dipilih dari pisang yang matang dicuci dengan air bersih yang mengalir selanjutnya kulit pisang dipotong menjadi bagian kecil dengan ukuran kurang lebih 1 x $0,5 \mathrm{~cm}$ menggunakan pisau dan direndam ke dalam larutan Natrium metabisulfit selama 10 menit. Kulit pisang kepok kemudian dikeringkan menggunakan oven dengan suhu $60^{\circ} \mathrm{C}$ selama 12 jam. Setelah kering selanjutnya digiling hingga halus menggunakan blender lalu diayak untuk mendapatkan partikel tepung yang seragam.

\section{Proses Pembuatan Bolu Kukus Substitusi Tepung Kulit Pisang Kepok (Andie, Hadi 2014 yang dimodifikasi)}

Semua bahan ditimbang sesuai dengan resep. Sebanyak 100 gram gula, telur (150 gr), bahan pelembut/emulsifier (SP) (10 gr) dikocok dengan mixer selama 10 menit dan ditambahkan Baking Powder (5 gr) dan margarin cair (40 gr). Campuran ditambahkan tepung terigu sesuai formulasi, tepung kulit pisang sesuai formulasi, dan susu bubuk (45 gr) sedikit demi sedikit. Adonan kemudian dituangkan ke dalam loyang yang sudah diolesi oleh margarin dan dikukus selama 15 menit dengan api besar.

\section{Formulasi Bolu Kukus Tepung Kulit Pisang Kepok}

Formula bolu tepung kulit pisang kepok disajikan pada Tabel 1.

Tabel 1. Formula bolu tepung kulit pisang kepok (Musa Paradisiaca)

\begin{tabular}{|c|c|c|c|c|}
\hline Bahan-bahan & Kontrol $\left(\mathrm{F}_{0}\right)$ & $F_{1}(45 \%)$ & $F_{2}(50 \%)$ & $\mathrm{F}_{3}(55 \%)$ \\
\hline $\begin{array}{l}\text { Tepung kulit pisang } \\
\text { Kepok }\end{array}$ & $0 \mathrm{~g}$ & $45 \mathrm{~g}$ & $50 \mathrm{~g}$ & $55 \mathrm{~g}$ \\
\hline Tepung terigu & $100 \mathrm{~g}$ & $55 \mathrm{~g}$ & $50 \mathrm{~g}$ & $45 \mathrm{~g}$ \\
\hline Telur & $150 \mathrm{~g}$ & $150 \mathrm{~g}$ & $150 \mathrm{~g}$ & $150 \mathrm{~g}$ \\
\hline Margarin & $40 \mathrm{~g}$ & $40 \mathrm{~g}$ & $40 \mathrm{~g}$ & $40 \mathrm{~g}$ \\
\hline Gula pasir & $100 \mathrm{~g}$ & $100 \mathrm{~g}$ & $100 \mathrm{~g}$ & $100 \mathrm{~g}$ \\
\hline Bahan pelembut (SP) & $10 \mathrm{~g}$ & $10 \mathrm{~g}$ & $10 \mathrm{~g}$ & $10 \mathrm{~g}$ \\
\hline Baking Powder & $5 \mathrm{~g}$ & $5 \mathrm{~g}$ & $5 \mathrm{~g}$ & $5 \mathrm{~g}$ \\
\hline Susu & $45 \mathrm{~g}$ & $45 \mathrm{~g}$ & $45 \mathrm{~g}$ & $45 \mathrm{~g}$ \\
\hline Total Adonan & $450 \mathrm{~g}$ & $450 \mathrm{~g}$ & $450 \mathrm{~g}$ & $450 \mathrm{~g}$ \\
\hline
\end{tabular}




\section{HASIL DAN PEMBAHASAN}

\section{Uji Organoleptik Bolu Kukus}

Hasil analisis uji organoleptik bolu kukus substitusi tepung kulit pisang menunjukan pada atribut keseluruhan atribut penilaian $\mathrm{F}_{0}(0 \%)$ memperoleh nilai tertinggi dan $\mathrm{F}_{2}(50 \%)$ mendapat penilaian tertinggi pada atribut rasa.

Tabel 2. Hasil uji mutu substitusi terigu dengan tepung kulit pisang kepok

\begin{tabular}{ccccc}
\hline \multirow{2}{*}{ Formula } & \multicolumn{5}{c}{ Atribut } \\
\cline { 2 - 5 } & Rasa & Tekstur & Warna & Aroma \\
\hline $\mathrm{F}_{0}(0 \%)$ & $3,83^{\mathrm{b}}$ & $3,57^{\mathrm{a}}$ & $4,30^{\mathrm{c}}$ & $4,40^{\mathrm{b}}$ \\
$\mathrm{F}_{1}(45 \%)$ & $2,83^{\mathrm{a}}$ & $3,57^{\mathrm{a}}$ & $2,97^{\mathrm{b}}$ & $2,40^{\mathrm{a}}$ \\
$\mathrm{F}_{2}(50 \%)$ & $3,17^{\mathrm{a}}$ & $3,50^{\mathrm{a}}$ & $2,57^{\mathrm{a}}$ & $2,70^{\mathrm{a}}$ \\
$\mathrm{F}_{3}(55 \%)$ & $2,80^{\mathrm{a}}$ & $3,30^{\mathrm{a}}$ & $2,27^{\mathrm{a}}$ & $2,27^{\mathrm{a}}$ \\
\hline
\end{tabular}

Keterangan: $\quad$ Atribut rasa skala $1=$ sangat pahit hingga $5=$ sangat manis

Atribut tekstur skala $1=$ sangat keras hingga $5=$ sangat lembut,

Atribut warna skala $1=$ cokelat tua sampai 5 = kuning keemasan,

Atribut aroma skala $1=$ sangat langu sampai $5=$ sangat wangi khas pisang.

Huruf yang beda pada baris yang sama menunjukkan perbedaan yang nyata $(\mathrm{p}<0,05)$.

\section{Rasa}

Bolu tepung kulit pisang $\mathrm{F}_{0}$ memperoleh nilai kesukaan tertinggi terhadap rasa yaitu 4,27 (suka). Hasil uji mutu hedonik terhadap rasa, menunjukkan bolu tepung kulit pisang $\mathrm{F} 0$ memiliki rasa manis, sedangkan $\mathrm{F}_{1}(45 \%), \mathrm{F}_{2}(50 \%)$ dan $\mathrm{F}_{3}$ $(55 \%)$ memiliki rasa biasa saja.

Rasa bolu tepung kulit pisang semakin pahit seiring meningkatnya penambahan tepung kulit pisang yang semakin banyak. Hal ini disebabkan oleh adanya kandungan fitokimia saponin pada tepung kulit pisang, saponin merupakat fitokimia yang memberikan citarasa pahit pada bahan pangan nabati. serta dapat pula disebabkan oleh kandungan tanin pada kulit pisang kepok. Tanin merupakan bahan aktif yang bersifat pahit (Lumowa \& Bardin, 2018).

\section{Tekstur}

Atribut penilaian tekstur pada bolu tepung kulit pisang kepok meliputi sangat keras sampai sangat lembut. Hasil penilaian organoleptik uji hedonik menunjukkan bahwa bolu tepung kulit pisang kepok $\mathrm{F}_{0}$ memperoleh nilai kesukaan tertinggi terhadap tekstur yaitu 3,57 (suka). Hasil uji mutu hedonik terhadap tekstur menunjukkan bolu tepung kulit pisang kepok $\mathrm{F}_{0}(0 \%), \mathrm{F}_{1}(45 \%), \mathrm{F}_{2}(50 \%)$ dan $\mathrm{F}_{3}$ $(55 \%)$ memiliki tekstur lembut. Perbedaan tekstur ini dapat disebabkan karena kandungan senyawa pektin yang terdapat pada kulit pisang, yang merupakan pembentuk gel, pengikat air dan penstabil sehingga dapat dimanfaatkan dalam 
produk pangan (Del Rosario \& Flores, 1981). Selain itu juga dapat membentuk gel atau memberikan tekstur kenyal pada produk (Hanum et al., 2012).

\section{Warna}

Atribut penilaian warna bolu tepung kulit pisang kepok meliputi coklat tua sampai kuning keemasan. Hasil penilaian organoleptik uji hedonik menunjukkan bahwa bolu tepung kulit pisang kepok $\mathrm{F}_{0}(0 \%)$ memperoleh nilai kesukaan tertinggi terhadap warna yaitu 4,45 (suka). Hasil uji mutu hedonik terhadap warna menunjukkan bolu tepung kulit pisang kepok F0 (0\%) berwarna kuning, untuk bolu tepung kulit pisang kepok $\mathrm{F}_{1}(45 \%)$ berwarna coklat, untuk bolu tepung kulit pisang kepok $\mathrm{F}_{2}(50 \%)$ dan $\mathrm{F}_{3}(55 \%)$ berwarna coklat muda.

Warna bolu tepung kulit pisang kepok cenderung coklat seiring meningkatnya penambahan tepung kulit pisang kepok yang semakin banyak. Hal ini karena tepung kulit pisang kepok mengalami reaksi browning pada saat pemrosesan pembuatan tepung kulit pisang yang diakibatkan dari reaksi oksidasi antara oksigen dengan senyawa fenol yang kemudian menjadi pigmen melaniadin yang berwarna coklat (Mardiah, 1996). Selain itu warna coklat pada bolu kulit pisang juga dapat disebabkan oleh adanya reaksi pencoklatan (reaksi Maillard) karena adanya reaksi antara karbohidrat dan asam amino yang menyebabkan terjadinya pencoklatan (Datunsolang, 2018).

\section{Aroma}

Hasil penilaian organoleptik uji hedonik menunjukkan bahwa bolu tepung kulit pisang kepok $\mathrm{F}_{0}(0 \%)$ memperoleh nilai kesukaan tertinggi terhadap aroma yaitu 4,53 (suka). Hasil uji mutu hedonik terhadap aroma menunjukkan bolu tepung kulit pisang kepok F0 (0\%) memiliki aroma bau wangi, untuk bolu tepung kulit pisang kepok $\mathrm{F}_{1}(45 \%)$ dan $\mathrm{F}_{3}(55 \%)$ memiliki aroma langu, untuk bolu tepung kulit pisang kepok $\mathrm{F}_{2}(50 \%)$ memiliki aroma biasa saja.

Aroma bolu tepung kulit pisang kepok memiliki perubahan aroma seiring meningkatnya penambahan tepung kulit pisang kepok dan dapat dipengaruhi oleh reaksi Maillard karena tingginya kandungan karbohidrat pada tepung kulit pisang. (Agustini et al., 2015). Reaksi maillard dalam makanan dapat berfungsi untuk menghasilkan flavor dan aroma, Penggunaan natrium metabisulfit pada proses pembuatan tepung kulit pisang kepok juga dapat menghambat reaksi browning enzimatis (Corzo-Martínez et al., 2012).

\section{Penentuan Formula Terpilih Bolu Kukus}

Formula terpilih ditentukan berdasarkan hasil uji tingkat kesukaan (hedonik). Penilaian formula terpilih berasal dari nilai kesukaan secara keseluruhan. Rasa adalah 
atribut sensoris yang sangat menentukan penerimaan panelis. Berdasarkan hasil uji mutu hedonik $\mathrm{F}_{2}$ memiliki karakteristik rasa biasa saja $(3,15)$, tekstur yang biasa saja $(3,50)$, warna coklat muda $(2,57)$, aroma biasa saja $(2,70)$.

\section{Analisis Kimia Bolu Kukus}

Analisis proksimat yang dilakukan adalah kadar air, kadar abu, lemak, protein, dan karbohidrat. Data hasil analisis pada formula terpilih dijelaskan secara deskriptif dan dibandingkan dengan formula kontrol, serta dilakukan uji beda (Independent Sample T-test) untuk mengetahui adanya perbedaan antara formula kontrol dan formula terpilih. Hasil analisis proksimat bolu tepung kulit pisang kepok formula kontrol dan formula terpilih disajikan pada tabel 3.

Tabel 3 Hasil analisis proksimat bolu kukus

\begin{tabular}{|c|c|c|c|}
\hline Komponen & Formula Kontrol (\%b/b) & $\begin{array}{c}\text { Formula Terpilih }(50 \%) \\
(\% \mathrm{~b} / \mathrm{b})\end{array}$ & $p$-value \\
\hline Kadar Air & 31,00 & 31,60 & 0,168 \\
\hline Kadar Abu & 1,05 & 2,78 & $0,026 *$ \\
\hline Lemak & 3,83 & 5,97 & $0,004 *$ \\
\hline Protein & 10,95 & 10,97 & 0,950 \\
\hline Serat & 2,02 & 1,91 & 0,656 \\
\hline Karbohidrat & 53,17 & 48,68 & $0,004^{*}$ \\
\hline
\end{tabular}

\section{Kadar Air dan Abu Bolu Kukus}

Air merupakan komponen yang penting dalam bahan makanan karena air dapat mempengaruhi penampakan, tekstur, serta cita rasa makanan. Kandungan air dalam bahan makanan ikut menentukan daya terima, kesegaran, dan daya tahan bahan makanan. Kadar air untuk formula kontrol sebanyak 31\% sedangkan untuk formula terpilih (50\%) sebanyak 31,60\%. Berdasarkan hasil uji beda (Independent Sample t-test), kadar air bolu tepung kulit pisang formula kontrol tidak berbeda nyata dengan bolu tepung kulit pisang formula terpilih.

Kadar air pada produk bolu kukus tepung kulit pisang kepok masih berada dalam batas aman (SNI 01-3840-1995 kadar air bolu kukus maksimal 40\%). Kadar air pada produk bolu kukus tepung kulit pisang kepok lebih tinggi bila dibandingkan dengan formula kontrol, hal ini dapat disebabkan oleh adanya serat, khususnya serat larut air berupa pektin. Kulit pisang kepok mengandung pektin yang mampu mengikat air dengan baik sehingga dapat meningkatkan kandungan air daripada pati yang terdapat dalam tepung terigu (Darojat, 2010).

Selain kadar air, dilakukan juga analisis kadar abu. Kadar abu untuk formula kontrol sebanyak 1,05\%, sedangkan pada formula terpilih sebanyak 2,78\%. Berdasarkan hasil ujibeda (Independent Sample T-test), kadar abu formula kontrol berbeda nyata $(\mathrm{p}<0,05)$ dengan bolu tepung kulit pisang pada formula terpilih. Hal ini sejalan dengan penelitian Histifarina et al., (2012) menyatakan bahwa kandungan 
kadar abu kulit pisang kepok adalah 2,08\%. Kadar abu yang tinggi dapat mengindikasikan bahwa mineral yang terkandung tinggi (Muchtadi et al., 2010).

\section{Kadar Lemak Bolu Kukus}

Lemak merupakan komponen zat gizi yang memiliki peranan penting bagi tubuh. Selain sebagai sumber energi, lemak diperlukan oleh tubuh sebagai pelarut vitamin larut lemak, komponen membran sel sebagai hormon, sistem imun, dan termoregulator (Wiardani et al., 2011). Kadar lemak pada formula kontrol sebanyak 3,83\%, sedangkan pada formula terpilih sebanyak 5,97\%.

Kadar lemak formula terpilih lebih tinggi daripada formula kontrol. Kadar lemak yang tinggi pada formula terpilih dipengaruhi oleh kadar lemak pada tepung kulit pisang kepok yaitu sebesar 4,4\% (Djunaedi, 2006). Lemak dan minyak hampir terdapat di dalam semua bahan pangan dengan kandungan yang berbeda-beda. Kandungan asam lemak pada tepung kulit pisang antara lain asam lemak ganda tak jenuh (PUFA), terutama asam linoleat dan $\alpha$-linolenat, Kandungan asam lemak pada tepung kulit pisang antara lain lemak tak jenuh 5,15\%, asam lemak ganda tak jenuh (PUFA) 3,82 \%, terutama asam linoleat 2,28\% dan $\alpha$-linolenat 1,53\% serta mengandung asam lemak omega 3, 6, dan 9 (Tionika \& Septiani, 2019). Lemak tersebut memiliki peran berperan penting dalam transpor dan metabolisme lemak, fungsi imun, mempertahankan fungsi dan integritas membran sel. (Sartika, 2008).

\section{Kadar Protein Bolu Kukus}

Protein merupakan zat gizi yang sangat penting bagi tubuh, karena zat ini selain berfungsi sebagai penghasil energi dalam tubuh juga berfungsi sebagai zat pembangun masa otot dan meningkatkan komposisi tubuh. (Harahap, 2014). Kadar protein pada formula kontrol 10,95\% sedangkan formula terpilih yaitu 10,97\%. Berdasarkan hasil uji beda (Independent Sample T-test), kadar protein bolu tepung kulit pisang formula kontrol tidak berbeda nyata dengan bolu tepung kulit pisang formula terpilih.

Kadar protein formula terpilih tidak berbeda nyata dibandingkan formula kontrol. Hal ini menunjukkan bahwa formulasi tepung terigu yang ditambahkan berpengaruh terhadap kandungan protein bolu kukus yang dihasilkan. Hal ini disebabkan karena pada tepung pisang kandungan proteinnya lebih rendah dibandingkan kadar protein tepung terigu. Kadar protein tepung kulit pisang menurut Djunaedi (2006) hanya 9,86\%, sedangkan kadar protein tepung terigu 10,33\% (USDA Nutrient Database, 2018).

Protein memiliki banyak manfaat bagi tubuh manusia diantaranya mengatur proses-proses metabolisma dalam bentuk enzim dan hormon dan sebagai mekanisme pertahanan tubuh melawan berbagai mikroba dan zat toksik lain yang 
datang dari luar, serta memelihara sel dan jaringan tubuh. Dalam bentuk kromosom, protein juga berperan dalam menyimpan dan meneruskan sifat-sifat keturunan dalam bentuk gen (Diana, 2009).

\section{Kadar Serat Bolu Kukus}

Kadar serat pada formula kontrol 2,02\% sedangkan formula terpilih yaitu 1,91\%. Berdasarkan hasil uji beda (Independent Sample T-test), kadar serat bolu tepung kulit pisang formula kontrol tidak berbeda nyata dengan bolu tepung kulit pisang formula terpilih. Hal ini tidak sejalan dengan penelitian yang dilakukan oleh Devi, Puji Ardiningsih, Nora Idiawati (2019) tentang kandungan gizi dan organoleptik cookies tersubtitusi tepung kulit pisang kepok bahwa kadar serat A1 (100\% tepung terigu) dan A2 (substitusi tepung kulit pisang) adalah 1,497 dan 3,979\%.

Perbedaan hasil penelitian ini karena pada saat proses pembuatan tepung kulit pisang kepok, serat yang terdapat pada tepung tidak lolos pada saat penyaringan atau pengayakan sehingga kadar serat pada tepung kulit pisang kepok yang digunakan dalam penelitian ini menjadi lebih sedikit.

\section{Kadar Karbohidrat Bolu Kukus}

Kadar karbohidrat dihitung dengan menggunakan metode by Different diasumsikan sebagai kandungan selain air, abu, lemak, dan protein. Hasil analisis menunjukkan bahwa kadar karbohidrat pada formula kontrol sebesar 53,17\% sedangkan pada formula terpilih sebesar 48,68\%. Berdasarkan hasil uji beda (Independent Sample T-test) setelah melakukan uji normalitas, kadar karbohidrat bolu tepung kulit pisang formula kontrol berbeda nyata $(p<0,05)$ dengan bolu tepung kulit pisang formula terpilih.

Kadar karbohidrat formula kontrol lebih tinggi dibandingkan formula terpilih. Karena kandungan karbohidratnya kulit pisang berpontensi sebagai sumber pati untuk pembuatan tepung kulit pisang.

\section{KESIMPULAN}

Terdapat perbedaan yang nyata $(\mathrm{p}<0,05)$ antara formula terpilih terhadap kadar abu, lemak, dan karbohidrat. Formula terpilih $\mathrm{F}_{2}(50 \%)$ ini mempunyai kadar air sebesar 31,60\%, kadar abu sebesar 2,78\%, lemak sebesar 5,97\%, protein sebesar 10,97\%, serat sebesar 1,91\%, karbohidrat sebesar 48,68\%. Berdasarkan uji ragam pada uji mutu hedonik rasa, warna dan aroma penampilan terdapat pengaruh yang nyata $(\mathrm{p}<0,05)$ sedangkan pada atribut tekstur tidak terdapat pengaruh nyata. Berdasarkan uji hedonik, formula terpilih adalah produk bolu tepung kulit pisang dengan substitusi $0 \%$ dan $50 \%\left(\mathrm{~F}_{2}\right)$. 


\section{UCAPAN TERIMA KASIH}

Penulis mengucapkan terimakasih kepada para pihak yang telah memberi dukungan dan kontribusi terhadap penelitian ini.

\section{DAFTAR PUSTAKA}

Agustini, S., Priyanto, G., Hamzah, B., Santoso, B., \& Pambayun, R. (2015). Pengaruh modifikasi proses terhadap kualitas sensoris kue delapan jam. Jurnal Dinamika Penelitian Industri, 26(2), 107-115.

AOAC. (2012). Official Methods of Analysis of AOAC International (19th ed.). AOAC International.

Apriyantono, A., Fardiaz. D, N.L, P., \& S, B. (1989). Petunjuk Laboratorium Analisis Pangan. IPB-Press.

Badan Pusat Statistik. (2017). Produktivitas pisang nasional. Badan Pusat Statistik Nasional.

Corzo-Martínez, M., Corzo, N., Villamiel, M., \& Castillo, M. D. del. (2012). Food biochemistry and food processing. In B. K. Simpson, L. Nollet, \& G. P. and S. Benjakul (Eds.), Food Biochemistry and Food Processing (2nd ed., pp. 56-83). John Wiley \& Sons. https:/ / doi.org/10.1002/9781118308035

Darojat, D. (2010). Manfaat penambahan serat pangan pada produk daging olahan. Jurnal Pangan Dan Gizi Vol 1(2). Food Review, 5(7), 52-53.

Datunsolang, I. (2018). Pembuatan Bolu dengan Substitusi Tepung Pisang Goroho. $\begin{array}{lllll}\text { Gorontalo Agriculture Technology } & 19 .\end{array}$ https://doi.org/10.32662/gatj.v1i1.163

Del Rosario, R. R., \& Flores, D. M. (1981). Functional properties of four types of mung bean flour. Journal of the Science of Food and Agriculture, 32(2), 175-180. https://doi.org/10.1002/jsfa.2740320213

Devi, Puji Ardiningsih, Nora Idiawati, I. C. (2019). Kandungan gizi dan organoleptik cookies tersubtitusi tepung kulit pisang kepok ( Musa paradisiaca Linn ). Jurnal Kimia Khatulistiwa, 8(1), 71-77.

Diana, F. M. (2009). Fungsi dan metabolisme protein dalam tubuh manusia. Jurnal Kesehatan Masyarakat, 4(1), 49.

Djunaedi, E. (2006). Pemanfaatan limbah kulit pisang sebagai sumber pangan alternatif dalam pembuatan cookies. Universitas Pakuan Bogor.

Hanum, F., Kaban, I. M. D., \& Tarigan, M. A. (2012). Ekstraksi pektin dari kulit buah pisang raja (musa sapientum). Jurnal Teknik Kimia USU, 1(2), 21-26.

Harahap, N. S. (2014). Protein Dalam Nutrisi Olahraga. Jurnal Ilmu Keolabragaan, 13(2), 38-44.

Histifarina, Rahcman, A., Rahadian, D., \& Sukmaya. (2012). Teknologi pengeolahan tepung dari berbagai jenis pisang menggunakan cara pengeringan matahari dan mesin pengering. Jurnal Agrin, 16(2).

Kumara, F. M., \& Purwani, E. (2017). Pengaruh substitusi tepung kimpul (xanthosomasagittifolium) terhadap tingkat pengembangan dan daya terima bolu. Nutri-Sains, 1(2).

Lumowa, S. V. T., \& Bardin, S. (2018). Uji fitokimia kulit pisang kepok (musa 
paradisiacal.) bahan alam sebagai pestisida nabati berpotensi menekan serangan serangga hama tanaman umur pendek. Jurnal Sains Dan Kesehatan, 1(9), 465469. https://doi.org/10.25026/jsk.v1i9.87

Mardiah, E. (1996). Penentuan aktivitas dan inhibisi enzim polifenol oksidase dari apel (Pyrus malus Linn.). Jurnal Kimia Andalas, 2(2), 16-18.

Megarani, S., \& Srimiati, M. (2018). Pengaruh substitusi tepung biji alpukat terhadap sifat organoleptik sponge cakE. Nutri-Sains: Jurnal Gizi, Pangan Dan Aplikasinya, 2(2), 31-38.

Muchtadi, T. R., Sugiyono, \& Ayustaningwarno, F. (2010). Ilmu pengetahuan bahan pangan. Alfabeta.

Sartika, R. A. D. (2008). Pengaruh asam lemak jenuh, tidak jenuh dan asam lemak trans terhadap kesehatan. Kesmas: National Public Health Journal, 2(4), 154. https://doi.org/10.21109/kesmas.v2i4.258

Tionika, S. A., \& Septiani. (2019). Identifikasi tepung kulit pisang kepok terhadap kadar proksimat menggunakan metode pengeringan oven. Binawan Student Journal, 1(3), 131-136.

USDA Nutrient database. (2018). Wheat flour, white, all-purpose, unenriched. United States Department of Agriculture.

Wiardani, N. K., Sugiani, P. P. S., \& Gumala, N. M. Y. (2011). Konsumsi lemak total, lemak jenuh, dan kolesterol sebagai faktor risiko sindroma metabolik pada masyarakat perkotaan di Denpasar. Jurnal Giẓi Klinik Indonesia, 7(3), 107. https://doi.org/10.22146/ijcn.17751 
Halaman ini sengaja dikosongkan. 